\title{
The Realistic Dilemma and Promoting Path of Secondary Vocational Education Talent Training Model under the Background of Education Supply- side Reform
}

\author{
Yonghua Wang, Difan Xu, Tingrui Luo, Yajing Lai \\ Jiangxi Agricultural University Vocational Teachers College, Nanchang 330045, Jiangxi Province, China
}

\begin{abstract}
In today's world, the competition for high-end smart technology is becoming increasingly fierce, and the huge connotation hidden behind the fierce competition is the competition of high-quality skilled talents. The status of secondary vocational education in our country's education system has a solid foundational role. The close connection it exhibits with social and economic development is beyond the reach of other types of education. However, the current secondary vocational education talent training model shows a situation that is not in line with market demand, and problems such as "shortage of skilled personnel" and "unemployment structural imbalance" have appeared in related fields. The supply of talents in secondary vocational education lacks a balanced mechanism, lacks in quality of supply, and does not have a high effect. It is urgent to train high-quality skilled talents with matching socio-economic structure transformation and upgrading for the society through education supply-side reform measures. In view of this, according to the changes in market demand, we will vigorously promote the reform of the school-based curriculum of secondary vocational schools, strive to create a new integrated development model that combines textbooks and practice, promote in-depth exchanges and cooperation between schools and characteristic enterprises in the industry, and train people in practice. Cultivating people, creating a good atmosphere for cultivating technical talents, and combining with the new goal of practicing education to build an evaluation system suitable for the growth of secondary vocational talents, making the human resource structure more and more suitable for the transformation and upgrading of the current social industrial structure.
\end{abstract}

Keywords: Education supply side; Secondary vocational education; Talent training model; Realistic dilemma; Advancing path

Publication date: April, 2021; Publication online: 30 April, 2021

*Corresponding author: Yonghua Wang, 822426659@qq.com

\section{Introduction}

In today's world, the competition for high-end smart technology is becoming increasingly fierce, and the huge connotation hidden behind the fierce competition is the competition of high-quality talents. The comprehensive quality of human capital is related to the quality of national economic development. At present, my country's education supply side is facing many risks and is under pressure from economic transformation. The talent training model of secondary vocational education shows a trend that is not in line with market demand. The talent training structure cannot match the transformation and upgrading of the industrial structure. The unemployment problem of talents is becoming more and more serious. Secondary vocational education has played a key role in cultivating a large number of technical and skilled personnel and high-quality labor. In the process of promoting the implementation of education supply-side reform, secondary vocational education needs to play a more important role. 


\section{The necessity of research}

The education supply side is the supplier of education policies, systems, resources, products and services. The focus of the education supply side is to expand the effective supply of education, eliminate ineffective supply, and improve the quality of supply ${ }^{[1]}$. The new call for reform of the education supply side has laid a solid foundation for the development of secondary vocational education, which is facing the new development process, explores the important problems facing the development of secondary vocational education today, and puts forward that it is in line with the education supply side. The optimization strategy of the secondary vocational education talent training model under the background of the reform is to improve the gradual weakening of secondary vocational education, improve the quality of secondary vocational education talent supply, and more profoundly coordinate the development of secondary vocational education theory and practice, and provide secondary vocational education. The development of educational practice provides a new type of theoretical support.

\section{Practical dilemmas faced by secondary vocational education personnel training models.}

\subsection{The design of the talent training system for secondary vocational education lacks structural considerations.}

From the perspective of the construction of modern vocational education system, vocational education and ordinary high school education are often split in the development process, and there is a lack of effective standards to restrict the effective connection between secondary vocational education diplomas and skills development. In the strict sense, vocational education at different stages has not shown the effective role of integrated education, which leads to structural imbalances in the process of talent employment. In the process of cultivating skilled talents, secondary vocational education sets the goal of talent training too vaguely. In the related professional and technical curriculum setting link, it fails to study and judge the demand pattern of talents in the new environment in a timely manner. It relies on the past training experience to set up the society. The existence of so-called popular majors has caused the lack of professionalism of skilled talents, and the training of professional talents is facing a situation of "uneven hot and cold."

\subsection{School-enterprise cooperation encounters policy difficulties}

Nowadays, school-enterprise cooperation lacks the necessary support in related policies, especially the lack of necessary guarantees in relevant laws and regulations. Under the framework of the existing basic system of laws and regulations, the institutional mechanism to encourage enterprises to participate in the integration of production and education is not yet complete, and the definition of rights and obligations of schools and enterprises remains in the original narrow scope. The integration of industry and education and school-enterprise cooperation lack a complete cooperation mechanism, and the interests of both parties are difficult to negotiate and resolve ${ }^{[2]}$. On the one hand, the talents cultivated by secondary vocational colleges do not meet the employment needs of enterprises, so that the enthusiasm of enterprises to participate in schoolenterprise cooperation cannot be guaranteed. On the other hand, companies generally aim for profit and lack the sense of cooperation. Enterprises usually think that cooperating with schools to train talents cannot bring considerable income, but will increase the cost of talent training, and the motivation to participate in secondary vocational education is insufficient.

\subsection{The quality of teachers is generally not high.}

Secondary vocational schools are also faced with many dilemmas of insufficient number of teachers and imbalance of teacher structure, which are mainly manifested in the following aspects: First, the number of professional teachers is insufficient, and the teachers that meet the daily teaching of the school are far from reaching the required standards. The second is the imbalance in the structure of the teaching staff, which is manifested in the lack of high- 
end talents, the poor qualifications of the academic leaders, and the "double-qualified" teacher talents cannot meet the needs of vocational schools for talent training. Third, the number of teachers with advanced skills is far from the standard, which makes it impossible for vocational schools to popularize advanced skills in daily classroom teaching.

\subsection{Lack of innovative talents.}

With the introduction of Made in China 2025, my country's demand for high-quality skilled talents has shown a spurt of growth. The shortage of high-tech talents faced by my country's advanced manufacturing and modern service industries is mainly reflected in the fact that the knowledge and skills of secondary vocational school graduates cannot meet the employment needs of enterprises, especially the lack of high-level innovative talents and high-level compound technical talents ${ }^{[3]}$. However, my country's secondary vocational schools have not been able to improve their school-running ideas in a timely and effective manner, which has caused the supply of secondary vocational education personnel to be out of touch with social needs in terms of quantity, structure, and quality, especially in the urgent need to resolve the industrial transformation and upgrading. In terms of innovative technical talents, the talents cultivated by secondary vocational schools still cannot meet the qualification standards of the market.

\section{The promotion path of secondary vocational} education talent training mode under the

\section{background of education supply side reform}

\subsection{The teaching of secondary vocational education courses is based on students.}

In the context of education supply-side reforms, secondary vocational schools should adhere to the fundamental task of establishing morality and fostering people, combined with the relevant policies of vocational education, fully embody the people as the key and the primary task in the teaching process, and show that the secondary vocational education respects talents. , The consistent philosophy of cherishing and protecting talents. In daily course teaching, it is necessary to inculcate students with textbook concepts and at the same time supplement them with effective practical exercises to enhance students' practical operation ability, so that they can go to work in the future with ease. In addition, the school should also carry out in-depth exchanges and cooperation with characteristic enterprises in the industry, so that students who have obtained theoretical learning can go to the front line of production to be exercised and learn to improve students' practical ability and vocational skills, so that students can cultivate their own skills while meeting the needs of employment. Work quality and improve the dilemma of low efficiency in secondary vocational education training ${ }^{[4]}$.

\subsection{Increasing the guarantee of funds for training talents in secondary vocational education.}

At present, the proportion of funds invested in the training of secondary vocational education talents is showing an unbalanced trend. In economically backward areas, the training funds for secondary vocational education talents are relatively scarce, and they lag far behind economically developed areas. The local government should pay enough attention to improve the difficult situation of secondary vocational education personnel training based on the local natural resources environment, industrial model, economic development level, education development level and other comprehensive conditions. It is necessary to adjust the distribution structure of public funds for secondary vocational education, establish a diversified funding input mechanism, build advanced internship training bases in line with the new environment, and strengthen cooperation and exchanges with characteristic enterprises to achieve a winwin situation. Only after having an effective and suitable funding structure, can the secondary vocational education talent training model usher in a new development situation, improve the appropriate distribution plan in regional allocation, improve the lack of structural balance in the past talent training, and continuously improve the secondary vocational education. The core quality of vocational education personnel training.

3.3 Speeding up the construction of "dualprofessional" teachers. 
Parents in our country are generally affected by the old educational concepts and believe that secondary vocational education is backward education, that is, education that lacks competition. The level of development of secondary vocational education is often not as good as that of general education. Affected by this, the status of teachers of secondary vocational education is usually not as good as that of ordinary education. Therefore, it is necessary to change the single teacher teaching system that existed in secondary vocational education, accelerate the introduction of "double-qualified" teachers, and guide students through teachers with theoretical and practical levels. Better development. At the same time, employees with high quality levels in the enterprise can be invited as part-time teachers at secondary vocational schools to build a faculty with high-quality talents to expand the knowledge structure of students, strengthen the close combination of theory and practice, and improve secondary vocational schools. The quality of vocational education talent supply ${ }^{[5]}$.

\subsection{Implement diversified management to achieve effective supply}

In the context of education supply-side reform, secondary vocational education should break the inherent management ideas, combine market demand for labor and the development of students, and continue to introduce new models of secondary vocational education management in a new environment, so that secondary vocational education can cultivate talents It is closer to the reality of production and life, and is more accepted by enterprises. At the same time, the government must also assume the responsibility of top-level design and participate in the training of secondary vocational education talents with enterprises and industries, including the establishment of talent training goals, the construction of professional and curriculum-related systems, the content of curriculum teaching arrangements, and the improvement of evaluation systems. The school must steadily promote the development of school-enterprise cooperation, fully understand the needs of the company for the comprehensive quality of employees and ensure the ultimate implementation of the effectiveness of secondary vocational education personnel training.

\section{Conclusion}

How to optimize the development of secondary vocational education talents under the background of the education supply-side reform, continue to export high-quality laborskilled talents with innovative consciousness to the country and society, increase the income level of the middle-class people, and boost the construction of China's human resources power country will be the future middle-class The key element of the reform of the vocational education talent training model is to effectively train new talents in response to market requirements by clarifying training goals; introducing a new model of theory combined with practice in the training process, so that the quality of talent training can continuously meet the development level of the market; With the cooperation of characteristic enterprises, research and formulate high-quality secondary vocational talent training models suitable for enterprise development; build and improve training systems and mechanisms, and establish an effective evaluation system. Let more secondary vocational education talents obtain better job opportunities through appropriate training.

\section{References}

[1]Zhou HT, Zhu YC. Several relations of supply-side reforms in the education field[J]. Educational Research, 2016, 37(12): 30-34.

[2]Xu M. Theoretical tracing and advancing path of supplyside structural reform in the field of vocational education[J]. Adult Education, 2018, 38(6): 72-75.

[3]Sun L. Re-understanding of the training objectives of secondary vocational education $[\mathrm{J}]$. Vocational Education Forum, 2008(11): 6-9.

[4]Deng ZM, Su BC, Zhao P. Research on the Curriculum System of Secondary Vocational Education [J]. China Vocational and Technical Education, 2008(27): 37-40.

[5]Wang CY. The overall construction of my country's modern vocational education system[J]. China Vocational and Technical Education, 2017(32): 